\title{
THE COMPENSATION OF EXPERT WITNESSES
}

\author{
Horace L. Bomar, JR.*
}

Witnesses who attend trial at the command of the court and give testimony are entitled to compensation provided by statute, and to mileage fees, which likewise are regulated by statute. The expert, ${ }^{1}$ who has given testimony, is, of course, entitled to this remuneration just as is any other witness. However, in most states this will amount to a relatively insignificant sum, ranging from fifty cents per day and mileage fees in Connecticut, ${ }^{2}$ to $\$ 5$ per day and mileage fees in certain populous counties of Michigan. ${ }^{3}$ Obviously such compensation does not satisfy the expert witness, who, in most instances, is a highly trained and experienced man whose time and talents are valuable.

The problem presented would not be a particularly difficult one if experts were drawn entirely from one profession to give only one type of testimony. But the group is a large one. It is composed not only of physicians, surgeons, toxicologists and specialists in handwriting, but extends to "the great army of experts who are daily before the courts of the country testifying as to matters of civil enginecring, insurance, printing, publishing and binding, mining and a dozen other occupations and callings which at least in some of their features involve matters beyond the scope of ordinary knowledge of the ordinary man."4

Likewise, services rendered by experts of the same type are by no means alike in all cases nor are they restricted to giving testimony on the witness stand. A physician, for example, may examine a person whose injuries have given rise to the litigation, conduct an autopsy or make a chemical analysis. Again, he may be called upon to study the facts and circumstances of the case before trial, so that he will be qualified to give a first-hand opinion on all the evidence. His constant attendance at court during the trial may be called for; in some situations the physician may even act

\footnotetext{
- B.A., 1933, Furman University. Now member of the third year class in the Duke University School of Law. President, Duke Bar Association.

1 The expert witness, as distinguished from the ordinary witness, is one who has had special training or experience on a matter in issue. The ordinary witness is summoned to testify to facts which any other person in his position might give. He is called merely because of his personal knowledge of certain facts pertinent to the case before the court, and as a general rule will not be permitted to express his opinion. The expert, on the other hand, is called primarily for the purpose of securing his opinion.

${ }^{2}$ Conn. Gen. Stat. (1930) \$2263.

${ }^{3}$ Mrch. Comp. Laws (r929) $\$ 15468$.

"Wade, The Office of the Expert Witness (1904) I AM. L. Scrool REv. 225.
} 
as medical counsel, advising the lawyer as to questions which he should ask in examining a witness on medical issues. ${ }^{5}$

Services rendered by the trained and experienced man as a witness on the stand also vary considerably. He may be called on merely to relate facts. In some instances this testimony will be in no wise different in character from that of any other witness; ${ }^{6}$ in others, the facts may be such that only the expert would know or appreciate them. ${ }^{7}$ In these latter situations, the special knowledge and training of the expert enable him to prove facts which the lay witness would entirely fail to grasp. However, the expert, in rendering an opinion and thus aiding judge and jury in determining the significance of facts, is playing his principal rôle. This opinion may sometimes be based on facts which are within his personal knowledge. Again, it may be given as an answer to a hypothetical question, embracing facts testified to by others. ${ }^{8}$

Since the compensation claimed will vary according to the measure and class of service performed, just what is done by the expert in each case should be kept in mind. It may be that he is called upon to act in only one of these capacities; more often, however, his aid consists of a combination of the different types of service. From the standpoint of compensation, however, the situations may best be classified with reference to whether the services have or have not been rendered on the basis of a contract with the party calling him.

\section{Compensatton of Expert in Absence of Express Contract}

The question of the compensation of experts in the absence of an express agreement has been a bone of contention for some time, particularly with doctors. Practically all writers on medical jurisprudence, for obvious reasons, contend that it is unfair to exact services of the expert without provision for a reasonable fee. ${ }^{9}$

This problem may be brought before the court in two principal ways. As a general rule-in civil cases, at least-a witness will not be held in contempt for refusing to testify unless the statutory witness fees have been paid or tendered in

\footnotetext{
- The practice of acting as expert counscl and expert witness in the same case has been severely criticized. One lawyer remarks: "I have always argued there should be a clear line of distinction drawn between the functions of a medical expert witness and the functions of a medical expert counsel in a case. ... That the same man, after having been employed and paid as a medical counsel, should go upon the witness stand and swear as a medical expert witness to tell the truth, the whole truth, and nothing but the truth, is a public scandal and one which lawyers and courts should not tolerate. $32 \mathrm{~N}$. Y. Bar Ass'N REP. 392-393 (1909).

- Thus, a physician who fortuitously happened to see an automobile smash-up might be subpoenaed to tell his version of the accident.

${ }^{7}$ Thus, the physician who witnessed the automobile wreck could relate to the jury the type of injuries resulting and certain medical facts concerning them, whereas the ordinary witness could supply no such information.

- The witness may or may not have been familiar with these facts prior to the posing of the question.

${ }^{\circ}$ For citations of views to this effect, see RAPAIJE, Witnesses (I887) 533 n. I.

${ }^{10}$ Id. $\$ 302$ (3).
} 
advance. ${ }^{10}$ In refusing to testify ${ }^{11}$ without tender of a reasonable fee in addition to that provided by statute, the expert may raise the question of whether he is liable to compulsory process unless a special fee is tendered beforehand. The court must either sustain him in refusing to testify or punish him for contempt. ${ }^{12}$ The question of compensation is also raised where the expert testifies with or without objection and later sues for a fee in addition to that allowed the ordinary witness by statute. ${ }^{13}$

All courts agree that special services other than giving testimony on trial may not be required of the expert without payment or promise of a special fee, for such services are not within the duty of any witness. Hence, a professional man is entitled to demand adequate compensation before undertaking a chemical analysis, a postmortem examination, or any other work which is done with. a view to pronouncing a considered opinion upon particular circumstances of the case. ${ }^{14}$ Likewise, after rendering these services, he is entitled to recover their reasonable value of the party at whose instigation he performed them.

Whether an additional charge may be demanded as a condition precedent to an obligation to give testimony on trial is a more perplexing problem. Usually a distinction between testimony as to fact and opinion evidence is made. A subdivision of factual testimony so as to differentiate between testimony concerning ordinary facts and facts which only the expert could satisfactorily prove might be made, but this is not usually done. ${ }^{15}$ It seems to be generally held that it is the duty of the expert to testify as to facts albeit those facts would only be appreciated by the expert. ${ }^{16}$ The expert witness, in the discharge of his duty as a citizen, is like any other person compellable to attend court in obedience to process, and testify as to what he may know, for the same statutory fees as other witnesses.

Where the expert refuses to give his opinion until some arrangement is made for a reasonable compensation, courts are not in agreement as to whether such refusal

${ }^{21}$ It is generally admitted that the expert has no right to refuse to attend court. He must obey the subpoena to the extent of putting himself in readiness to testify. See Hutchins, The Compensation of Medical Witnesses (1906) 4 Mich. Law Rev. 413, 413. Cf. In re Roelker, I Sprague 276 (D. Mass. I854).

${ }^{23}$ The same question may also be put in issue by an appeal by one of the parties to the original suit, appellant contending that he was prejudiced in not having the testimony of an expert whom the trial judge refused to compel to testify. See Bradley v. Davidson, 47 App. D. C. 266 (Igr6); State v. Bell, 212 Mo. III, II S. W. 24 (1908); State v. Teipner, 36 Minn. 535, 32 N. W. 682 (1887); Webb v. Lewald Coal Co., 2r 4 Cal. 182, 297 Pac. 958 (r93

${ }^{23}$ Although the question is usually raised in an action against the party calling the expert to recover a fee, it may also be raised when a party appeals from an order taxing costs.

${ }^{14}$ See Ex parte Dement, 53 Ala. 389, 397 (1875); Flinn v. Prairie County, 60 Ark. 204, 207, 29 S. W. 459, 460 (1895); Board v. Lee, 3 Colo. App. 177, 179, 32 Pac. 841, 842 (1893); 4 Wigmore, Evidence (2d ed. 1923) 684 .

${ }^{25}$ In some cases the language used is so broad and ambiguous that it is impossible to tell whether the court is speaking of facts as well as opinion. See, e.g., U. S. v. Howe, Fed. Cas. No. 15,404a (W. D. Ark., I881); Sumners v. State, 5 Tex. App. 365 (1879).

${ }^{10}$ See Brown County v. Hall, 6r S. D. 568, 569, 249 N. W. 253, 253 (1933); Philler v. Waukesha County, 139 Wis. 211, 2I4, r20 N. W. 829, 830; 2 Hamilton, A System of Legal. Medicine (1894) 148; Herzog, Medical Jurisprudence (r93 I) \$ro4.

In England where an additional fee is allowed to experts for opinion evidence, one writer has intimated that the expert witness may be entitled to an additional fee for giving testimony as to medical facts. See (1933) 2 BRIT. MED. J. 627. 
amounts to a contempt. In the early English case of $W e b b$ v. Page ${ }^{17}$ a witness had been called by the plaintiff to testify as to the damage sustained by certain cabinet work and the expense necessary to restore or replace the injured articles. The witness having demanded compensation before testifying, Mr. Justice Maule, in deciding the point, said: "There is a distinction between the case of a man who sees a fact and is called to prove it in a court of law, and a man who is selected by a party to give his opinion on a matter on which he is peculiarly conversant from the nature of his employment in life. The former is bound, as a matter of public duty, to speak to a fact which happens to fall within his own knowledge; without such testimony the course of justice must be stopped. The latter is under no such obligation; there is no such necessity for his evidence, and the party who selects him must pay him." 18 This case seems to have established the English common law rule which sustains the expert in refusing to give opinion evidence in the absence of an arrangement for the payment of an additional compensation. ${ }^{19}$

Some few courts in this country have followed the English rule. ${ }^{20}$ An early American case endorsing this doctrine is Buchman v. State, ${ }^{21}$ which holds that a physician or surgeon may not be required to testify as to his professional opinion without the compensation of a professional fee, and that his refusal to so testify unless so compensated is not a contempt. ${ }^{22}$ American courts following this view have advanced the following arguments in support of their position: (I) The expert should be compensated for his loss of time, for time is especially valuable to him. ${ }^{23}$ (2) The knowledge of the professional man is his property-his "stock in trade" where the expert is a physician or lawyer whose opinion is valuable to him as a primary means of livelihood ${ }^{24}$-and he should not be compelled to contribute it in

\footnotetext{
${ }^{27}$ I Carr. \& K. $23(1843)$. ${ }^{18}$ Id. at 23-24.
}

10 "In the very early days of English Practice it was customary to pay lawyers and physicians and possibly clericals and statesmen or others competent from position or study to give expert testimony in a case extra compensation for such services. And it is quite evident that the statute of 5 Eliz. ch. 9 merely formulated this pre-existing custom by providing that witnesses should be paid according to their countenance and calling, a reasonable sum." Robbins, Allowance of Extra Compensation for Expert Witnesses (rgo8) 66 CENr. L. J. 37. This custom under the statute gradually narrowed itself down until the only experts who were given any extra compensation for their services were lawyers and doctors. For some time they received a guinea a day for loss of time. See Webb v. Page, supra note I7.

${ }^{30}$ Harvey v. Evansville Steam Packet Co., 8 Bliss 99, Fed. Cas. No. 6,179 (C. C. D. Ind. 1877); U. S. v. Howe, supra note I5; U. S. v. Cooper, 21 D. C. 491 (1893); Dills v. State, 59 Ind. 15 (1887); Buchman v. State, 59 Ind. I (1887); People v. Montgomery, I3 Abb. Prac, (N. S.) 207, (N. Y. I872); Tiffany v. Kellog Iron Works, 59 Misc. Ir3, 109 N. Y. Supp. 754; (1908); Pennsylvania Co. v. Philadelphia, $262 \mathrm{~Pa} .439$, 105 Atl. 630 (1918).

${ }^{2}$ This holding is expressly confined to physicians and others "whose opinions are valuable to them as the source of their income and livelihood." It was later nullified by a statute expressly providing that an expert witness is compellable to testify for the ordinary witness fee. See note 57 , infra.

2 See Buchman v. State, 59 Ind. at 3.

${ }^{2}$ U. S. v. Cooper, 21 D. C. 491, 493 (1893). See Strqyker, Courts and Doctors (1932) 166, where it is said: "The physician has as much right to be compensated for his store of goods, namely, his knowledge, as has the grocer for his cans of tomatoes or his green vegetables on his shclves. . . " Sed quaere as to this analogy. When the grocer's cans or vegetables are taken, the taking leaves nothing of value to the grocer, whereas the expert's ability to render further opinions is unimpaired after one opinion has been exacted by the court. 
the form of opinions without adequate compensation..$^{25}$ (3) A denial of reasonable compensation would place an undue burden on the most eminent members of a profession or trade, who, it is claimed, would be compelled to testify in an inordinate number of cases with only the compensation of the ordinary witness. ${ }^{26}$ (4) In civil cases the expert is conferring a benefit on the individual litigant for which he should pay. ${ }^{27}$

Provisions of the federal and state constitutions have often been urged as compelling the adoption of the English rule. In the Constitution of Indiana in force at the time Buchman v. State came before the Indiana court, was a provision that "No man's particular services shall be demanded without just compensation." ${ }^{28}$ The Indiana court concluded that exacting the expert's opinion amounted to a demand for "particular services." A provision similar to the one above is not commonly found in state constitutions. The constitutional argument more frequently used is that an expert's opinion is his property, the taking of which without adequate compensation is a deprivation of property without due process-forbidden by both federal and state constitutions.

These arguments have been termed "specious,"30 and the overwhelming weight of authority in the United States today, in the absence of statute or express agreement as to compensation, denies the existence of a right to special compensation for rendering an opinion. In a number of cases it is held that the expert may be declared in contempt of court if he persistently refuses to give expert testimony ${ }^{31}$ in others suit in quantum meruit $t^{32}$ by the expert who has furnished opinion evidence has been defeated. $^{33}$ Many arguments have been advanced in support of this position-some

\footnotetext{
${ }^{25}$ Buchman v. State, supra note 2I; Tiffany v. Kellog Iron Works, 59 Misc. x×3, I I4, 109 N. Y. Supp. 754, 755 (I908); U. S. v. Cooper, 21 .D. C. 491,493 (1893).

${ }^{\infty}$ Buchman v. State, 59 Ind. at 13 : "If physicians and surgeons can be compelled to render professional services, by giving their opinions on the trial of criminal causes, then an eminent physician or surgeon may be compelled to go into any part of the state at any and all times, to render such services without other compensation than such as he may recover as an ordinary witness."

However, it would seem that the court might interpose as it has in England, to prevent this privilege from being used oppressively. See Raymond v. Tapson, $22 \mathrm{Ch}$. Div. 430 (I882).

One writer ${ }_{2}$ believing that the burden of giving testimony would curtail time available for charity patients, terms the majority rule "anti-social." STryker, Courts AND Doctors, I66. Another writer applies the same epithet to the minority rule. 3 Chamberlayne, Evidence (IgII) \$237I.

${ }^{27}$ Pennsylvania Co. v. Philadelphia, $262 \mathrm{~Pa} .439$, I05 Atl. 630 (1918).

23 IND. Const. ( $185 \mathrm{I}$ ) Bill of Rights, \$2r.

$\approx 59$ Ind. at 13 . The court relied on Blythe v. State, 4 Ind. 525 (1853), holding that an attorncy, appointed by the court to defend an indigent defendant could not be compelled to give his services with-
} out a reasonable compensation.

${ }^{30} 4$ WigMORE, EVIDENCE (2d ed. 1923) $\$ 2203$.

${ }^{31}$ Ex parte Dement, 53 Ala. 389 (1875); Wright v. People, 112 Ill. 540 (1884); Dixon v. People, 168 III. 179, 48 N. E. 108 (1897); State v. Darty, 7 Ohio Dec. 725 (1886); Sumners v. State, 5 Tex. App. 365 (1879).

${ }_{82}$ For the lay reader, quantum meruit may be defined as the name of the formula for pleading an indebtedness founded on work done or services rendered, not under a special contract as to compensation, but under such circumstances that the law will imply a promise to pay the one performing the work or service as much as he deserved. See Shipman, Common Law Plending (3rd edz 1923) \$6r.

${ }^{83}$ Clark County v. Kerstan, 60 Ark. 508, 30 S. W. 1046 (1895); Flinn v. Prairic County, supra note 14, Note (1895) 27 L. R. A. 669; McClenahan v. Keyes, 188 Cal. 574, 206 Pac. 454 (r922); Fairchild v. 
to refute arguments of courts following the English rule; others to advance additional reasons for denying compensation in addition to that allowed the ordinary witness. Among them are the following: (r) Loss of time for which the expert witness claims to be entitled to extra compensation is a sacrifice that every witness must make, the hardship in the expert's case being no greater relatively than in the case of the ordinary witness, ${ }^{34}$ and those urging additional compensation because of the value of the expert's time have been unduly influenced by English statutes placing lawyers and doctors in a preferred class. ${ }^{35}$ (2) It is the duty of witnesses to give all testimony available to aid in the administration of justice. ${ }^{36}$ (3) Although in giving testimony in civil actions the expert may incidentally be conferring a benefit on the individual litigant, he is primarily aiding the administration of justice in giving his opinion. ${ }^{37}$ (4) It is, as a practical matter, impossible to draw a line between testimony as to fact, for which no extra compensation is paid, and testimony as to opinion rendered by an expert; indeed, it is argued by some that a witness' opinion is merely another "fact" for the consideration of the court, ${ }^{38}$ and by others that all testimony as to the existence of facts is really opinion evidence-the opinion of the witness that certain facts are true. ${ }^{39}$ (5) It is also impracticable to make a distinction between the different kinds of expert testimony in determining the appropriate remuneration. ${ }^{40}$ (6) The payment of higher fees to experts would result in an

Ada County, 6 Ida. 340, 55 Pac. 654 (1898); Chicago \& M. Ry. Co. v. Judge, 135 Ill. App. 377 (I907); Burnett v. Freeman, I25 Mo. App. 683, 103 S. W. I2I (1907); Main v. Sherman County, 74 Neb. 155, 103 N. W. 1038 (I905); Fonda v. Bolton, 6 N. J. L. J. 240 (1883); In re Yarlotte's Guardianship, 133 Okla. 3, 270 Pac. 321 (1928); Ealy v. Shelter Ice Cream Co., 108 W. Va. 184, I50 S. E. 539 (1929); Philler v. Waukesha County, supra note 16.

The question of the expert's right to special compensation may also be raised when a party appeals from an order taxing costs. See, e.g. Bathgate v. Irvine, 126 Cal. 135, 58 , Pac. 442 (1889); In re Clark, I04 Mass. 537 (1870); Ulaski v. Morris \& Co., 106 Neb. 782, I84 N. W. 946 (I92I); Lyon v. Wilkes, I Cow. 591 (N. Y. 1823).

"See 4 WIGMORE, Evidence \$2203: "The hardship upon the professional man who loses his day's fees of fifty or one hundred or more dollars is no greater, relatively, than upon the storekeeper or the mechanic who loses his day's earnings of two dollars or ten dollars; cach loses his all for the day; moreover, though the recoupment of the witness fee of one or two dollars is relatively greater for the mechanic, yet his risk of losing continued employment by enforced absence is greater than for the professional man, and more than equalizes the hardship to him."

However, a distinction should be made between the salaried employee and the professional man. Usually, the former (mechanic or storekeeper) will draw his salary without diminution, whereas the latter's absence from his work will normally mean a loss of income.

${ }^{25}$ Philler v. Waukesha County, 139 Wis. $211,216,120$ N. W. 829, 831 (1909). See note 19, supra.

${ }^{*}$ Ex parte Dement, supra note $3 \mathrm{I}$. "Many courts take the attitude that it becomes a public duty for the expert witness to aid justice without expecting specific compensation therefor, just as they expect persons to perform jury duty, also sometimes at a definite loss for those compelled to perform it." Sheffel, Medicai Jurisprudence (I93I) 172.

${ }_{37}^{7}$ See Dixon v. People, r68 Ill. 179, I9x, 48 N. E. 108, ir (1897).

ss 'It would seem on principle. . . that, if from the witness' observation or from hypothetical facts stated to him he has consciously in mind, either knowledge or an opinion, such knowledge or existing opinion is a fact as to which he may be required to testify. ..." Philler v. Waukesha County, 139 Wis. 21I, 215, 120 N. W. 829, 830 (1909). See also Mayor of N. Y. v. Pentz, 24 Wend. 668, 675 (1840).

${ }^{20}$ See Correspondence between Frazer and Penrose, 50 U. of PA. L. Rev. 346 (igo2).

wo "The practical difficulty of discriminating between various kinds of experts and their carnings .... would be serious, and would introduce confusion and quibbling into the law." 4 Wigmore, EvidenCE $68 x$. 
intolerable increase in the cost of litigation. ${ }^{41}$ (7) The argument that to compel the giving of an expert opinion without payment of extra compensation is unconstitutional as a deprivation of property is met by a denial that the expert has a property right in his opinion. In support it is contended that knowledge of fact is as much a property right as an opinion based on fact, and that no one will contend that the ordinary witness may demand an extra fee for parting with a property interest. ${ }^{42}$ (8) Finally, the followers of the rule of Ex parte Dement, a leading case denying a right to special compensation, have countered with a constitutional provision, found in most states, declaring that "in criminal prosecutions accused shall have the right to have compulsory process for obtaining witnesses in his favor." ${ }^{143}$ It is contended that this right will be denied an indigent defendant who is unable to pay an expert's fee if the expert is allowed to withhold his opinion until a special fee has been assured. ${ }^{44}$

In most cases, however, no distinction is taken between civil and criminal cases in determining the duty of the expert to testify without extra emolument. Where the opinion of the expert is exacted for the ordinary fee, it seems to be generally held that this obligation exists in civil as well as criminal cases. ${ }^{45}$ In both instances, the theory is that the witness is performing a public duty in aiding in the administration of justice. However, in Pennsylvania it is held that a witness cannot be compelled for the ordinary witness fee to testify in favor of a private litigant, though it is his duty to give testimony unreservedly in a criminal case. ${ }^{46}$

The question whether an expert could be compelled to testify at all upon questions of a scientific character, it has been observed, ${ }^{47}$ was at first one of difficulty. However, as we have seen, in the majority of states the expert cannot, without being placed in contempt of court, refuse to testify, even though he is to receive no more than the ordinary witness' fee. In those states which confer on the expert the right to obtain extra compensation for his testimony a question of some difficulty remains as to the expert's rights if the reasonableness of the amount of remuneration he demands is disputed. However, it has been held that there is a duty to testify after "reasonable fees" beyond the statutory feès "have been tendered. . .."48 Certainly there should be no doubt on this point. To allow the expert to demand a prohibitive fee and refuse to testify would be to allow him to defeat justice by withholding testimony necessary for a proper determination of the case.

\footnotetext{
${ }^{4}$ See Flinn v. Prairie County, 6o Ark. 204, 207, 29 S. W. 459, 459 (I895).

'2Dixon v. People, 168 Ill. 179, 192; 48 N. E. 108, 110 (1897). Various definitions have been given of "property." See Property Restatement (Am. L. Inst. 1929) Introductory Note. Since the term is such a flexible one, a statement that an opinion is property is hardly more than the statement of a result based on other considerations.

${ }^{43}$ See, e.g., Ind. Const. (185r) \$13, Art. I; Ohio Const. (1802) Art. VIII, 511; Wis, Const, Art. I, SVII.

"See State v. Darby, supra note 3r, at 726.

${ }^{4}$ Dixon v. People, 168 Ill. 179, 192; 48 N. E. 108, 110 (1897).

${ }^{48}$ Pennsylvania Co. v. Philadelphia, supra note 27.

${ }^{47}$ U. S. v. Cooper, 2 I D. C. 49 I (1893).

sid. at 493 .
} 
The collection of the fee due the expert after rendering his service presents something of a different question. When the expert presents a bill for services the party calling him must either have the charges taxed as costs or must pay the expert from his own resources. However, since the ultimate power to impose costs must be found in a statute, it is generally held that, in the absence of any statutory provision authorizing it, the compensation of experts beyond the regular witness fees is not a necessary disbursement and cannot be taxed as costs. ${ }^{49}$ It is considered as having been incurred for the party's own benefit, and is no more a disbursement in the cause than the fees paid to an attorney. ${ }^{50}$ Hence, in the absence of a statute allowing the expert additional compensation, ${ }^{51}$ it seems that, as a general rule, he must look to the party calling him for any fee in addition to the per diem and mileage allowed the ordinary witness.

Of course, there can be no recovery against the party calling the expert in those jurisdictions which hold that opinions may be exacted without special compensation having been paid, provided the expert's claim is based on his service as a witness. ${ }^{52}$ But all courts agree that where services other than testifying have been performed at the request of a party without any agreement as to compensation, an implied promise on the part of the litigant to pay a reasonable fee is found by the court, and a recovery sustained. $^{53}$ These services, however, must be performed at the request of a party or his attorney; where the expert voluntarily makes an investigation and is later called to the stand to reveal his findings, no additional compensation is allowed for the investigation. 54

In jurisdictions following the minority rule it would seem that a recovery in quantum meruit would be allowed an expert whose only service consisted of giving opinion evidence. ${ }^{55}$ In New York, however, where the expert is not bound to give his opinion without additional compensation, there is dictum in one case stating that the right to increased remuneration for testifying is waived if special compensation is not demanded at the outset. "It seems reasonable and should be the law," the court

${ }^{\circ}$ See Dixon v. People, I68 Ill. I79, I87; 48 N. E. I08, 109 (1897).

${ }^{0}$ Lawson, Expert and Opinion Evidence (2d. ed. 1900) 3 I9. Such a result is easily understood in view of the general principle that statutes which give costs are not to be extended beyond the letter, but are to be strictly construed. See Cadwallader v. Harris, 76 Ill. 370 (I875); 23 AM. \& Eng. ENcxc. LAw 387 .

a Such statutes are discussed subsequently, infra, p. 5 18. In the absence of express statutory provisions authorizing special fees to experts, it has been the practice in many states, in criminal cases, to make a proper compensation to experts summoned by the government or summoned by the defendant with the approval of the prosecutor. This is done under authority of certain statutory provisions authorizing the allowance of accounts for "necessary services and expenses." See Rogers, ExpERT TESTIMONY \$I95; In re Clark, 104 Mass. 537, 543 (1870).

${ }^{t a}$ See cases cited in first paragraph of note 33 , supra.

w Flinn v. Prairie County, supra note I4; Gordon v. Conley, I07 Me. 286, 78 Atl. 365; Allegheny County v. Watt, 3 Pa. Sup. 367 (I928); 4 Wigmore, Evidence (2d. ed. 1923) 684; Lawson, Expert AND OpINION EMtDence (2d. ed. 1900) 317.

* See Sumners v. State, 5 Tex. Cr. App. at 378.

${ }^{25}$ In this situation, the expert has performed a service which he was under no duty to perform. Cases on the precise point are lacking. See, however, Cohen v. Continental Casualty Co., 89 Pa. Sup. 367 (1928); U. S. v. Cooper, 21 D. C. 49 I (1893). 
declared, "that where one voluntarily testifies on request, without insisting on compensation as a condition of giving his evidence, he should not afterwards hold the person on whose behalf he testified to more than the statutory witness fee."

Not a few states have enacted statutes regulating the compensation of expert witnesses and authorizing or restricting the right to compensation in addition to that allowed the ordinary witness. ${ }^{57}$ Most of the statutes authorize allowance of additional compensation. Some are restricted to special types of experts; others relate

${ }^{60}$ Tiffany v. Kellog Iron Works, 59 Misc. 113, 115, 109 N. Y. Supp. 754, 755-756 (1908).

"Allowing Additional Compensation:

California. Caz. Code Civ. Proc. (Deering, 1931) 8187r. (Court may appoint experts and fix their compensation "for such services, if any, as [they] may have rendered, in addition to . . . their services as ... witnesses. . . ." In criminal cases the compensation fixed is a charge against the county; in civil cases "such compensation shall . . . be apportioned and charged to the several parties in such proportion as the court may determine and may thereafter be taxed ... as other costs." Other experts, called by the parties "shall be entitled to the ordinary witness fees only. . . .") court.)

Colo. Laws, 1933, c. I94 (Additional compensation allowed expert witnesses, amount to be fixed by

Cons. Gen. STAT. (r930) $\$ 5259$ ("Physicians shall receive a reasonable fee for services rendered in criminal cases".)

DeL. REv. CODE (1915) \$423I (Fees of experts witnesses are fixed by court in its discretion and taxed as costs.)

IowA CODE (1931) \$11329 ("Witnesses called to testify only to an opinion founded on special study or experience ... or to make scientific or professional examinations and state the result thereof, shall receive additional compensation, to be fixed by the court, . . . not [to] exceed four dollars per day. . . .")

LA. CODE OF PrAc. (Dart 1932) \$462 (Experts named by court in accordance with statutory scheme receive such compensation as court may determine, taxable as costs.)

ME. REv. StAT. (1930) c. 126,57 (Court in its discretion may allow to expert witness a sum not to exceed \$25.per day in taxing costs.)

3 MrCH. CoMp. LAws (I929) $\$ 14223$ (Person receiving or paying a larger fee than ordinary witness fee declared guilty of contempt unless court has awarded larger sum, as it may do, taxing such sum as costs.)

2 Mrnv. Stat. (Mason r927) \$7009 (Judge in his discretion may allow" expert "such fees as in his judgment may be just and reasonable.")

N. C. CODE (Michie, 1931) $\$ 3893$ ("Experts when compelled to attend and testify shall be allowed such compensation and mileage as the court may in its discretion order.")

R. I. GEN. LAws (1923) \$\$5002-5005 (Appointment of experts by judge before trial on motion of party, provided party moving pays reasonable fees, as fixed by judge, to court, such fee to be taxed as costs. "In criminal cases, in the discretion of the court, on request of defendant, expert witnesses may be furnished for such defendant at expense of the state.")

S. C. CoDE (1932) $\$ 4958$ (Physicians called by state or bound over at the instance of defendant to testify as experts "in any case of felony" receive $\$ 5$ in addition to ordinary witness fees, paid by the county where case is tried, provided trial judge certifies that the testimony of such expert is material.)

VT. GEN. Laws (I917) \$7443 ("In state causes, extra compensation may be allowed to expert witnesses only in case they have been previously selected, and their production ordered by a justice of the supreme court or a superior judge ... and such compensation shall be fixed by the court.")

Wis. STat. (1933) \$357.12 (In criminal eases judge appoints expert "whenever . . . expert opinion becomes necessary or desirable," compensation to be fixed by court and paid by the county as costs. Person paying or receiving more than such award declared guilty of. contempt. The parties may call other experts.)

Wyo. Rev. Stat. (1931) \$89-1602 (Physician allowed $\$ 5$ for balf day or less and \$1o for more than half day for testifying as expert before coroner.)

Denying Additional Compensation:

AIA. CODE (1928) \$7773 (Expert must testify without payment or tender of compensation other than ordinary witness fees.)

IND. STAT. (Baldwin 1934) \$310 (Expert must testify without tender or payment of compensation other than ordinary witness fees.)

MONT. CODE (1921) 54947 ("An expert is a witness and receives the same compensation as a witness.") 
only to court-appointed experts. ${ }^{58}$ Usually, the amount is left within the discretion of the court, although a maximum is stated by some statutes.59 Three states, on the other hand, have statutes which expressly provide that the expert must testify for the ordinary witness' fee. ${ }^{30}$

The statutes authorizing the court within its discretion to award extra compensation give no right to the expert to withhold his testimony until he is assured that he will receive the special fee, but only make provision for compensation after testimony has been given or other service performed. ${ }^{81}$ Furthermore, it has been held that such statutes do not apply to a witness to whom the facts are already known, merely because he possesses professional skill which may enable him to observe and recount those facts more intelligently. ${ }^{62}$ Only the fee earned as a witness may be taxed under most statutes; one or two are broad enough to cover services other than testifying. ${ }^{63}$ A question has arisen whether a witness must be appointed or summoned "as an expert" in order to be entitled to additional compensation under the statutes. Louisiana courts have held that the expert need not be summoned as such; ${ }^{64}$ the Iowa court seems to have reached an opposite result. ${ }^{65}$

\section{Contracts for Extra Compensation}

Where the expert serves in a contested case, as a practical matter, he usually does so as the result of an agreement with an interested party in regard to his compensation. A subpoena may or may not be served. In the great majority of cases, doubtless, the expert performs the agreed service and is compensated according to the contract. But at times a question of the validity of the agreement between the expert and the party calling him does arise. While a contract providing special compensation for services other than testifying will be upheld if free from improper conditions, there is some doubt as to its validity when made simply to secure the testimony of the expert. Of course, in those jurisdictions recognizing the right of the expert to demand a special fee as a condition precedent to an obligation to testify, the agreement for extra compensation is enforceable. ${ }^{.8}$ However, where the expert may be compelled to give his opinion after tender of the ordinary witness' fee, a contract for extra compensation for testifying will not as a general rule be enforced. ${ }^{.7}$

\footnotetext{
${ }^{58}$ See the Connecticut statute, supra note 57 , for an example of the former type; the Rhode Island statute, of the latter.

See Iowa and Maine statutes, supra note 57.

${ }^{\infty}$ See Alabama, Indiana, and Montana statutes, supra note 57.

${ }^{2}$ State v. Teipner, 36 Minn. 535, 32 N. W. 682 (188\%).

Anderson v. M., St. P. etc. Ry. Co., Io3 Minn. I84, II4 N. W. 744 (1908); (Ig09) 22 Harv. L. Rev. 235. The Michigan statute, supra note 57, expressly provides that provisions allowing stre:in: compensation shall not apply to witnesses testifying as to "established facts, or deductions of science. . ."

* See, e.g. Louisiana and Rhode Island statutes, supra note 57. Cf. the California statute, ibid.

Suthon v. Lawes, 132 La. 207, 21 I, 6I So. 204, 206 (1913) McQueen v. Union Indemnity Co., 136 So. 761,763 (La. App. 193I).

$C f$. Snyder v. Iowa City, 40 Iowa 646 ( $x 875)$.

$\approx$ Birch v. Sees, 78 App. Div. 609, 165 N. Y. Supp. 846 (1917).

${ }^{6}$ See Burnett v. Freeman, 125 Mo. App. 683, 691, 103 S. W. r21, I23 (Ig07); Klipper v. Klipper, 199 Ma. App. 294, 301, 202 S. W. 593, 595 (1918); Hutchins, supra note II, at 429.
} 
The claim of the expert is denied on the theory that no consideration is furnished by a promise by one to do what it is already his legal duty to do, and on the theory that such a contract is contrary to public policy. ${ }^{68}$ Yet, if no subpoena is served upon the witness so that he comes into court in response to his agreement, it is said that there is consideration for the promise of compensation, which will be enforced. ${ }^{89}$

In many cases where there is a contract between litigant and expert, the expert does work in addition to giving testimony. In such a case, it is not likely that the expert will experience any difficulty in recovering the stipulated compensation, though the fee was promised primarily to secure testimony and the giving of testimony actually constituted the chief objective of the bargain. Since the court does not ordinarily inquire into the adequacy of the consideration where it exists ${ }^{70}$ the disparity between fee and services would become material only if it were so great as to render the contract objectionable on grounds of public policy.

Courts have acted with unanimity in condemning any agreement by which the compensation of the expert is made contingent on or proportionate to a recovery. ${ }^{71}$ The reason for such a policy is obvious. Such contracts smack of champerty and tend strongly to induce perjured testimony. ${ }^{72}$ In fact they have been looked on with such disfavor that in one instance an attorney who negotiated a contingent fee contract with a dọctor was disbarred. ${ }^{73}$ In another instance the court recommended an investigation with a view to prosecution for contempt against a physician for collecting such a fee. ${ }^{74}$

\section{NeEd of Statutory Regulation}

Aside from contracts which are illegal and invalid, much criticism has been leveled at the general system of obtaining and paying for expert testimony by contract between the expert and the party calling him. Experts, though theoretically the impartial advisers of the court, are said to be zealous partisans. Many are claimed to be mere "intellectual soldiers of fortune."75 One writer has even stated that the enormous fee sometimes paid the expert is nothing short of bribery. ${ }^{76}$ In any event

Burnett v. Freeman, 125 Mo. App. at 69x; Collins v. Godefray, I Barn. \& Ad. 950, 952 (1831).

${ }^{\infty}$ See Dodge v. Stiles, 26 Conn. 463, 466-467 (1857); Walker v. Cook, 33 Ill. App. 56r, 565 (1889). In such a situation, the expert is not under a legal duty to testify.

${ }^{30}$ I WILIISTON, CoNTrnats (1926) $\$ 115$.

7 Miller v. Anderson, I83 Wis. I63, I96 N. W. 869 (I924); Pollok v. Gregory, 9 Bosw. II6 (N. Y. 186r); Sherman v. Burton, 165 Mich. 293, 130 N. W. 667 (I9r1); LAwson, op. cit. supra note 50, at 319.

72 "The plaintiff's interest in the amount of the recovery will furnish a powerful motive for exaggeration, suppression, and misrepresentation-a temptation to swell the damages so likely to color his testimony as to be inimical to the pure administration of justice and therefore invalid." Sherman v. Burton, 165 Mich. $293,297,130$ N. W. 667,668 (I9II). In case of attorneys, the courts, influenced by a desire to enable the poor litigant to prosecute his claim, have permitted the client to make a contract by which the attorney's fee is contingent upon success in the cause. See Schofield, Medical Expert Testimony; Methods of Improving the Practice (I9IO) I J. Crim. L. AND Crimin. 4I, 51.

7 Matter of Shapiro, 144 App. Div. I, 125 N. Y. Supp. 642 (rgrr).

7 See Davis v. Smoot, r76 N. C. $538,541,97$ S. E. 488,489 (r918).

${ }^{73}$ See Westenhauser, The Expert Winess (1905) 67 AlbaNy I. J. 2, 7.

${ }^{*}$ Rice, The Medical Expert as a Witness (1898) 10 GREEN BAG 464, 466. Another writer says, "To the jury an expert is an expert-a kind of intellectual prostitute ready to sell his opinions and enlist his 
it is undoubtedly true that expert evidence has largely fallen into discredit, and a principal feature of the breakdown seems to be the distrust of the expert witness, as one whose testimony is shaped by his bias for the party calling him.

The persistent agitation for reform of our system of expert testimony has been fertile in proposals for change ${ }^{77}$ but has yielded few statutes, ${ }^{78}$ and, except in limited fields, ${ }^{7 \theta}$ these seem not to have been significantly successful. It is hardly within the scope of this discussion to consider these plans in their entirety. However, the problem of compensation has been dealt with in most proposals for change and might well be singled out for special legislative consideration, for practically all proponents of reform agree that the amount and manner of the expert's compensation constitutes one of the chief abuses of the present system. The bias of the expert witness is undoubtedly due, in part, to the payment of a special fee by one of the parties litigant. In many situations the likelihood of partisanship is enhanced by contracts in which the fee of the expert is made contingent on a recovery. ${ }^{80}$ Even where there is no express condition in the contract, in many cases the effect is the same, for the ability of the litigant to pay will in many instances depend almost entirely on a recovery in the suit before the court.

Today, of the states having statutes which in one way or another expressly regulate the compensation which the expert is to receive, most, as has been observed, ${ }^{81}$ make the allowance of a special fee possible. Such statutes, however, are designed to pro-

services for the side that pays him." Friedman, Expert Testimony, Its Abuses and Reformation (Igro) I9 YALE L. J. 247.

"Court appointment of expert has long been advocated. Some would have the judge appoir" the experts on motion of parties or on his own motion from a panel of experts previously selected by the local medical society, or some similar professional group. Others would not so limit the judge. 'Dean Wigmore strongly believes that the expert should be summoned by the court and compensated by state or county. See I Wrgmore, Evidence $\$ 563$. Practically all would permit the parties to call additional experts.

The creation of an auxiliary panel of jurors, composed of experts, has been proposed, from which expert jurors would be drawn for cases involving scientific issues. See I Wigmore, Evidence \$563.

A scheme has even been proposed for a joint management of the trial by the judge and an expert presiding with him, the latter to direct and control the examination of expert witnesses and to sum up the expert testimony. before the judge's charge, subject to interrogation by counsel as to all points not previously developed. For a discussion of all the above schemes, see Endlich, Proposed Changes in the Law of Expert T.estimony (1898) 32 Ax. L. Rev. 851; see also McDermott, Needed Reforms in the Law of Expert Testimony (IgII) I J. Cris. L. \& CrImIN. 698; Schofield, supra note 72; I Wigmore, Evidence $\$ 563$.

A number of model bills have been proposed. Proposals in Massachusetts, Maine, and New York for legislation authorizing court appointment of experts are discussed in Friedman, supra note 76 . The New York and Maine bills, with accompanying discussion, are found in (1910) 32 N. Y. ST. B. A. REP. 377 et seq. See Melcher, Developing and Regulating Expert Testimony (19I7), 24 CASE AND COMMENT 38I, for a discussion of a Pennsylvania bill for court appointment of experts. The foregoing bills failed to pass:

${ }^{78}$ See the Michigan, Wisconsin, California, Rhode Island, and Louisiana statutes cited in note 57, supra.

7 Statutes providing for pre-trial psychiatric examination of criminal defendants have proved effective. See Weihofen, An Alternative to the Battle of Experts: Hospital Examination of Criminal Defendants before Trial, supra p. 4 rg.

${ }^{80}$ Whether or not an agreement of this kind is valid, it is one that is constantly made and carried out. See Hutchins, supra note 77 , at 429.

4 Supra p. 518. 
tect the expert; not to remedy the abuses of the fee system. Conceivably, an act might be passed placing the expert under an obligation to testify for the ordinary witness fee, and making it a criminal offense to pay or receive additional compensation. ${ }^{82}$ Regardless of preference for majority or minority rule, such a drastic limitation, with criminal sanction, on fees which may be paid raises grave difficulties. A denial of extra compensation puts a serious financial burden on honest experts, especially on those whose income is dependent on professional services. Furthermore, such a rule is easy of evasion so long as fees for services other than testifying are not covered by the act since the venal expert can always arrange to perform additional tasks and secure compensation therefor, which, although disproportionate, could not be proved to be such in criminal proceedings. And if fees for these services were not allowed, the whole system of expert testimony would break down since experts would refuse to make preliminary studies and examinations and could not be compelled to do so.

If regulation is to be desired and if the above difficulties are to be avoided, then it would seem that a model statute should make possible the award of an additional fee to experts, the amount of which should be within the discretion of the court. Compensation for preliminary services should be embraced by the fee. Statutory maxima seem defensible, if at all, only where the fee is limited to compensation for testifying. After provision is made for the allowance of an adequate fee, the statute should then make it a criminal offense to contract for additional emolument. Michigan and Wisconsin seem to be the only states, at present, with statutes containing the latter provision. An expert witness receiving or any person paying a sum larger than the amount awarded by the court is made guilty of contempt of court and, upon conviction, subject to fine or imprisonment, or both. ${ }^{83}$ Another form of regulation which might prove effective would be to forbid the introduction of expert testimony until the expert's fee has been made known to the court and approved by it. ${ }^{84}$

Yet it is doubtful that the alleged partisanship of expert testimony is due in many cases to witnesses who have sold out to the highest bidder. There are some selfstyled experts who are prepared to say anything for a fee, but it is notable that the vast majority of experts are honest. Much of the partisanship, perhaps, is due to an unconscious striving by the witness to support the cause of the party who will pay his fee, be it large or small. ${ }^{85}$ For this reason, payment of the expert out of the

\footnotetext{
The statutes of Alabama, Indiana, and Montana, supra note 57, provide that the expert can be compelled to testify for the ordinary witness fees, but place no restriction on what a party may pay him.

$\$$ Supra note 57. A model bill proposed by McDermott, supra note 77, at III, contains such a provision. Likewise, the Committee on Jurisprudence and Law Reform of the American Bar Association also recommended that this provision be included in expert testimony legislation. See (xg26) 5r A. B. A. REP. 428, 437.

The exclusion of expert evidence of a witness who has been paid or expects to receive anything except tho fees prescribed by law for his attendance at court has been suggested "by a judge of ability and much experience." Sec Bartlett, Medical Expert Evidence: The Obstacles to Radical Change in the Present System (1900) 34 Ax. L. Rev. 1, 7. This plan seemingly would allow the expert no fee above the ordinary witness fee unless a statute allowed special compensation.

* It has been said that the expert is "as capable as anyone else of persuading himself that he believes what he wants to believe." See Psycholocy in Court BY A Doctor (1933) 52.
} 
public treasury has been strenuously advocated by certain groups. ${ }^{86}$ Certainly it seems desirable that experts should not depend upon the parties for their emolument if they are to fulfill their office of impartial advisors or amici curiae, but a plan whereby they are to be paid out of the public funds is not altogether feasible. Expert testimony is costly. ${ }^{87}$ It goes without sàying that a stringent restriction on the number of experts would be necessary; without it, any proposal to have them publicly compensated would be absurd. Even with such a limitation, the expense of paying experts might still prove an intolerable burden for the machinery of justice. If the estimate that experts are employed in sixty per cent of the more important cases ${ }^{88}$ even approaches accuracy, their compensation out of the public purse would add hundreds of thousands of dollars to the burden of taxation in most states. ${ }^{80}$ This of itself may not be a conclusive argument, but, as one judge aptly said, "its weight cannot be disregarded in considering the practicability of the plan."90

Some modified form of public payment might be tried. In those states adopting a system whereby experts may be appointed by the court on its own motion or at the request of the parties, the state or county could compensate the court-appointed expert, other expert witnesses being called at the expense of the party desiring them. ${ }^{01}$ However, such a plan is still objectionable in that it leaves the problem of compensation unsolved as to those experts who will still look to the parties litigant for payment.

To make payment of the expert's compensation independent of the parties and yet relieve the public of the burden, a statute might require a litigant to give advance notice of an intention to call the expert, and require him to pay or give bond for

${ }^{80}$ Endlich, supra note 77, at 862; Note (Igro) I J. CrIM. L. \& Crimis. 125. See, also, bills proposed for Maine and New York discussed by Friedman, supra note 76, at 250, and changes advocated by the standing Committee on Jurisprudence and Law Reform of the American Bar Association, (1926) 5I A. B. A. REP. 428, 435. Public compensation of experts has also been advocated on the ground that it is a boon to the poor litigant, (Igro) 32 N. Y. ST. B. A. REP. $428,398$.

${ }^{87}$ See remarks of Judge Davy in opposition to statute proposed for New York providing for publie payment of expert medical witnesses. Id. at 398.

* Wellman, Art of Cróss Examination (1929) 6o. Schofield states that in Suffolk County (Mass.) about 600 out of 1146 cases tried in the superior court during the year ending in June, Igog, were personal injury suits. "One or more medical experts," he says, "testify in almost every personal injury case." Schofield, supra note 72, at 44 .

- The amount would be even more staggering if the parties are to be relieved of payment for services by experts other than testifying. And yet, if the expert is privately paid for such services, there is still the incentive for partisan testimony.

${ }^{\infty}$ Justice Willard Bartlett, supra note 84 , at ro.

${ }^{1}$ The framers of the California statute, supra note 57, apparently intended to limit the compensation of experts called by the parties to ordinary witness fees, but there is no criminal sanction to enforce this provision. This is also true of the bill proposed by the American Bar Association Committee which provides: ". . . 3. The court shall have power to fix the amount of the compensation to be paid to expert witnesses for their services, and the amount thus fixed shall be paid by the state; and the witness so called shall receive no other compensation." See (1926) 51 A. B. A. REP. at 437. The same plan was embodied in a bill prepared by the Massachusetts Medical Society and the Boston Bar Association. Id. at 440 . 
the expert's fee (as fixed by the judge) - at least, in civil cases-to the court before trial. The court would then pay the expert upon termination of the litigation. ${ }^{22}$

Despite the difficulties intrinsic to reform in this field, there are suggestions in existing statutes and the numerous proposals for reform which, if properly utilized, should go far toward enabling bar associations and judicial councils to frame measures which will so regulate the compensation of expert witnesses as to restrain the corrupt expert and his lawyer accomplices without impairing the important contributions which the unbiased expert can render in the administration of justice.

${ }^{-2}$ This seems substantially the plan of the California act, except that it seemingly provides additional compensation only for services other than testifying and no advance notice is required. The Rhode Island statute provides for the appointment of experts by the judge, provided the party moving for appointment pays reasonable fees, as fixed by the judge, to the court, the amount so paid to form part of the costs. Sce statutes cited in note 57 , supra. 